\title{
Receptor Specificity of a Glucocorticoid- and Stress-Induced Hippocampal Protein
}

\author{
Lawrence K. Schlatter ${ }^{1}$ and Linda A. Dokas ${ }^{1,2}$ \\ Departments of ${ }^{1}$ Biochemistry and ${ }^{2}$ Neurology, Medical College of Ohio, Toledo, Ohio 43699
}

Following treatment of rats with a subcutaneous injection of $5 \mathrm{mg}$ of corticosterone, hippocampal slices in vitro show increased labeling from ${ }^{35} \mathrm{~S}-$ methionine of a protein with an apparent molecular weight $\left(\boldsymbol{M}_{\boldsymbol{r}}\right)$ of 35,000 . Increased protein labeling is seen in response to corticosterone, dexamethasone, and aldosterone, steroids that associate with glucocorticoid receptors. Little or no response occurs after administration of progesterone or estradiol. Because the injected dose of steroids is high and responses to an injection of this magnitude may be pharmacological, several experiments have been done to determine whether stimuli that increase endogenous levels of corticosterone have the same effect on labeling of the $35,000 M_{r}$ protein. One hour after various stresses (immobilization, cold, ether, and sham-injection), when plasma levels of corticosterone are elevated, labeling of the $35,000 M_{r}$ protein is increased. Injection of ACTH also stimulates the synthesis of this protein in intact animals in a manner analogous to that seen with corticosterone injections. In addition, a dose-response curve for corticosterone with adrenalectomized rats shows that synthesis of the protein is maximally increased when the injected dosage causes serum levels of corticosterone to increase to the levels seen during stress. The increase in labeling of the $35,000 M_{r}$ protein in adrenalectomized animals is only half as great as that observed in intact animals. Injections of the type II glucocorticoid (GR) receptor agonist, RU 28362, into adrenalectomized rats differentially stimulates the synthesis of the $35,000 M$, protein compared with the mineralocorticoid aldosterone, which has a higher affinity for the type I (CR) receptor. These results indicate that the increase in synthesis of this protein is due to steroid interactions with the type II receptor and probably correlates with functions mediated by this receptor.

Glucocorticoid release by the adrenal cortex is a response to stress in mammals. In the rat, corticosterone is released into the serum following stress-induced ACTH release from the pituitary. The action of glucocorticoids varies depending upon the target tissue, for example, stimulation of gluconeogenesis in the liver (Granner and Beale, 1985), inhibition of the function of

\footnotetext{
Received June 16, 1988; revised Aug. 8, 1988; accepted Sept. 8, 1988.

We would like to thank Dick Dokas for performing the spot densitometry for this paper, Valerie Murphy for secretarial assistance, and Dr. Lee Meserve for his assistance with the adrenalectomies. The work was supported by grants from the Dorothy Van Ness-Thompson Foundation and the American Federation for Aging Research.

Correspondence should be addressed to Linda A. Dokas, Ph.D., Department of Biochemistry, Medical College of Ohio, C. S. 10008, Toledo, OH 43699.

Copyright (C) 1989 Society for Neuroscience $0270-6474 / 89 / 041134-07 \$ 02.00 / 0$
}

various cellular components of the immune system (Munck et al., 1984), and suppression of insulin secretion by the pancreas (Barseghian and Levine, 1980). In the hippocampus, glucocorticoids have been implicated in learning and memory formation (Bohus et al., 1982), aging (Sapolsky et al., 1986), and in the initiation of a negative-feedback loop to suppress ACTH synthesis and its release from the anterior pituitary (Feldman and Conforti, 1980). The mechanism of action of steroids has been shown to be via transcriptional events that take place after receptor binding in the nucleus (Fuxe et al., 1985), as a result of a direct response following membrane interactions (Reihold et al., 1984) and through modification of posttranscriptional (Vannice et al., 1984) or posttranslational (Karlsen et al., 1986) events. Specific changes in protein synthesis in the rat hippocampus as a result of various corticosterone treatments have been observed previously, including increases in the amount of protein I (Nestler et al., 1981), in labeling of a protein with an apparent $M_{r}$ of 54,000 from slices incubated with corticosterone and ${ }^{3} \mathrm{H}$-leucine (Etgen et al., 1979), in translation of proteins of $35,000,33,000$, and $20,000 M$, from hippocampal mRNA (Nichols et al., 1988), and in labeling from ${ }^{35} \mathrm{~S}$-methionine of a protein of $35,000 \mathrm{M}_{r}$ in hippocampal slices following in vivo corticosterone treatment (Schlatter and Dokas, 1987).

This paper will further elucidate the response in labeling of the $35,000 M_{r}$ protein after both pharmacological and physiological steroid manipulations in vivo. Protein synthesis in the rat hippocampus in response to elevated serum levels of corticosterone derived either endogenously through stress or ACTH injection or exogenously via corticosterone injection has been followed using incubation of a radiolabeled amino acid with slices obtained at various times after the serum levels of steroid were manipulated.

Two receptors for corticosterone, the corticosterone receptor (typc I, CR) and the glucocorticoid rcceptor (typc II, GR), have been reported in the rat brain (Reul and de Kloet, 1985). De Kloet and Reul (1987) have suggested that the type I receptor mediates tonic influences of corticosterone, while the type II receptor is involved with the feedback action of corticosterone on the stress-activated hypothalamic-pituitary-adrenal axis. The type II receptor has a lower affinity for corticosterone $\left(K_{d}\right.$ approximately 2.5-5 nM) than for the synthetic glucocorticoid analog RU 28362 ( $K_{d}$ approximately 1.2-2 nM), while the type I receptor has a high affinity for corticosterone with a $K_{d}$ of approximately $0.5 \mathrm{nM}$ (Reul and de Kloet, 1985). The type I receptor, in the absence of free corticosterone, will also bind aldosterone ( $K_{d}$ approximately 1.5-2 nM) (Veldhuis et al., 1982; de Kloet and Reul, 1987). Only one class of binding receptors in the rat brain has been shown for RU 28362 (Hermann et al., 1987), which would be the type II receptor. Thus, analysis of 

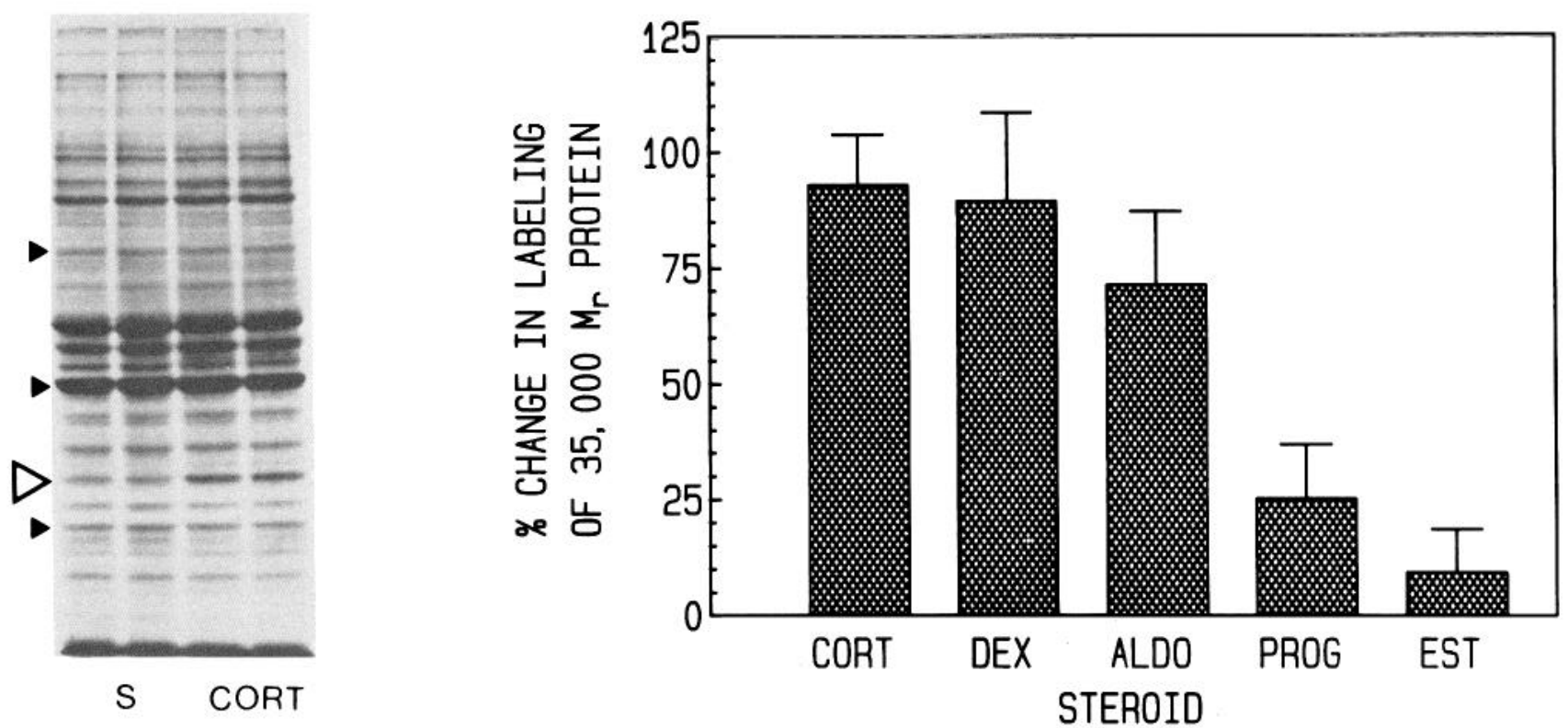

Figure 1. Incorporation of ${ }^{35} \mathrm{~S}$-methionine into hippocampal cytosolic proteins after injection of rats with various steroids. $A$, Fluorograph of an SDS-PAGE gel with samples in duplicate. Sham-injected $(S)$ animals were subcutaneously injected $4 \mathrm{hr}$ prior to death with $1 \mathrm{ml}$ sesame oil. Corticosterone-treated (CORT) rats were subcutaneously injected with $5 \mathrm{mg}$ corticosterone in $1 \mathrm{ml}$ sesame oil $4 \mathrm{hr}$ prior to death. Open arrowhead indicates location of the $35,000 \mathrm{M}_{r}$ protein; closed arrowheads indicate location of standards (nonradiolabeled) with known molecular weights of 66,000 $M_{r}$ (BSA), 45,000 $M_{r}$ (egg albumin) and 29,000 $M_{r}$ (carbonic anhydrase). B. Steroid specificity of the increase in labeling of the hippocampal $35,000 M_{r}$ protein. The percentage change in protein labeling was measured as the relative increase in density of the $35,000 M$, protein on fluorographs. Steroids $(5 \mathrm{mg})$ used were corticosterone $(C O R T)$, dexamethasone $(D E X)$, aldosterone $(A L D O)$, progesterone $(P R O G)$, and estradiol $(E S T)$.

rat hippocampal protein labeling after injection of aldosterone or RU 28362 into adrenalectomized rats has been done to elucidate the receptor specificity of the response.

\section{Materials and Methods}

Materials. Male Sprague-Dawley rats (100-150 gm) were ordered from Harlan Sprague-Dawley, Inc. (Indianapolis, IN). Enhance and ${ }^{35} \mathrm{~S}-\mathrm{me}-$ thionine (specific activity approximately $1100 \mathrm{Ci} / \mathrm{mmol}$ ) were from $\mathrm{Du}-$ pont-NEN, Inc. (Boston, MA). Corticosterone, dexamethasone, progesterone, $\beta$-estradiol, and $d$-aldosterone were obtained from Sigma Chemical Co. (St. Louis, MO). RU 28362 [11 $\beta, 17 \beta$-dihydroxy-6,21dimethyl-17 $\alpha$-pregna-4,6-trien-20-yn-3-one] (lot no. 2339-193) was also from Dupont-NEN, Inc. ACTH (40 USP units $/ \mathrm{ml}$ in $16 \%$ gelatin) was from Armour Pharmaceutical Co. (Kankakee, IL). ACS scintillation fluid was purchased from Amersham Co. (Arlington Heights, IL). Radioimmunoassay kits for determination of serum corticosterone were from Cambridge Medical Diagnostics (Billerica, MD).

Male Sprague-Dawley rats weighing between $150-200$ gm were subcutaneously injected with corticosterone, progesterone, dexamethasone, estrogen, aldosterone, or RU 28362 suspended in sesame oil. Injections were given at the beginning of the light cycle (6 AM-10 AM) to equalize any effect of the circadian rhythm of endogenously secreted corticosterone for all animals (Butte et al., 1976). Each animal received $5 \mathrm{mg}$ of steroid in $1 \mathrm{ml}$ sesame oil unless noted otherwise. Sham-injected animals received $1 \mathrm{ml}$ of vehicle only, while naive animals were not injected prior to death. The ACTH-injected animals each received 4 units from the stock solution diluted to $1 \mathrm{ml}$ with distilled water unless noted otherwise. Animal sacrifice, tissue preparation, radiolabeling, estimation of protein labeling by trichloroacetic acid (TCA) precipitation, electrophoresis, and densitometry were performed as described by Schlatter and Dokas (1987).

Briefly, blood for radioimmunoassays was collected by cardiac puncture from sodium pentobarbital-anesthetized animals previously treated as required by the experimental protocol (example: subcutaneous in- jection of $5 \mathrm{mg}$ corticosterone in $1 \mathrm{ml}$ of sesame oil $4 \mathrm{hr}$ prior to sacrifice). The animals were anesthetized to facilitate blood collection and to minimize stress at the time of death. Following blood collection, the rat was decapitated, and its hippocampus was removed and placed in cold KrebsRinger bicarbonate buffer (KRB). The hippocampus was sliced into 0.5 $\mathrm{mm}$ sections and incubated at $37^{\circ} \mathrm{C}$ for $3 \mathrm{hr}$ in fresh $\mathrm{KRB}$ with $80 \mu \mathrm{Ci}$ of ${ }^{35} \mathrm{~S}$-methionine in a $95 \% / 5 \% \mathrm{O}_{2} / \mathrm{CO}_{2}$ atmosphere following a $15 \mathrm{~min}$ preincubation under the same conditions without the radiolabeled amino acid. The slices were then homogenized in phosphate-buffered $(\mathrm{pH}$ 6.5) $0.32 \mathrm{~m}$ sucrose, and subcellular fractionation was performed on the homogenate with the first centrifugation for $10 \mathrm{~min}$ at $1000 \times \mathrm{g}$ and a final centrifugation of $100,000 \times g$ for $60 \mathrm{~min}$. An aliquot of the supernatant from the final centrifugation was precipitated with TCA and collected on glass fiber filters (Whatman GF/B), and the radioactivity measured. Equal cpm of each sample were then applied to an $11 \%$ SDSPAGE gel. The resultant gel was dried and after fluorography, the gels were exposed to Kodak XAR-5 x-ray film. The density of the 35,000 $M_{r}$ band on the film was recorded using a spot densitometer. The 0.5 $\mathrm{mm}$ tissue slice thickness has been reported to be the optimal thickness for incubation studies (Lust et al., 1982).

Adrenalectomy was performed in all cases on ether-anesthetized animals 5-7 d prior to their death. The 4 stresses used were $60 \mathrm{~min}$ of immobilization, $30 \mathrm{~min}$ at $4^{\circ} \mathrm{C}, 1 \mathrm{~min}$ of exposure to ether and shaminjection. The time from stress to death was considered to begin at the initiation of the stress. Protein concentrations were determined by the method of Lowry et al. (1951) with bovine serum albumin as a standard. Serum levels of corticosterone were measured by radioimmunoassay. The data were reported as the mean of each set of values \pm SEM.

\section{Results}

A subcutaneous injection of $5 \mathrm{mg}$ of corticosterone into intact rats $4 \mathrm{hr}$ prior to death causes an increase in $\left[{ }^{35} \mathrm{~S}\right]$-methionine incorporation into a protein with an apparent molecular weight $\left(M_{r}\right)$ of 35,000 when $0.5 \mathrm{~mm}$ hippocampal slices are incubated 

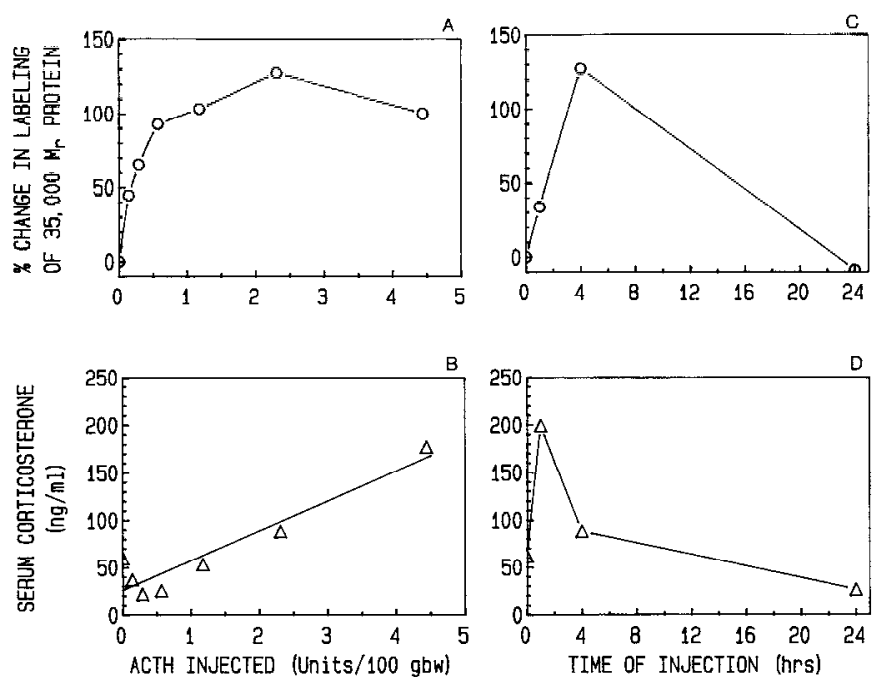

Figure 2. Dose-response curve and time course of changes in labeling of the $35,000 M$, hippocampal protein following ACTH injections in intact rats and corresponding serum corticosterone concentrations. $A$, Percentage change in labeling observed when 0.25-8.0 USP units of ACTH were subcutaneously injected per rat. All points are converted to units $/ 100 \mathrm{gm}$ body weight $(g b w)$. $B$, Corresponding serum corticosterone concentrations for the dose-response curve. $C$, The time course of increase in labeling of the $35,000 M_{r}$ protein in response to a subcutaneous injection of 4 USP units of ACTH into rats 1,4 , and $24 \mathrm{hr}$ prior to death. $D$, Corresponding serum corticosterone concentrations for the ACTH time course.

in $\mathrm{KRB}$ for $3 \mathrm{hr}$ in the presence of the radiolabeled amino acid (Fig. 1A). All increases in synthesis werc calculatcd by comparing the results from steroid- or ACTH-injected animals to those which were injected only with vehicle (sham-injected) to subtract any endogenous stress-induced increases in synthesis. The average increase in labeling of the $35,000 M_{r}$ protein in response to corticosterone was $97.7 \pm 10.3 \%(n=27)$.

When intact rats are injected with $5 \mathrm{mg}$ of dexamethasone, a synthetic glucocorticoid, the synthesis of this 35,000 $M_{r}$ protein was increased to the same extent $(89.5 \pm 18.9 \%, n=6)$ as that seen in response to corticosterone. The mineralocorticoid aldosterone at the same dose also increased the synthesis of this protein to a slightly lesser degree $(71.2 \pm 16.0 \%, n=9)$, which was not statistically different from the response to corticosterone or dexamethasone. Progesterone and estradiol $(5 \mathrm{mg})$ produced only minimal responses of $25.3 \pm 11.6 \%(n=4)$ and $9.4 \pm$ $9.3 \%(n=6)$, respectively (Fig. $1 B)$.

In order to determine if the increase in protein labeling oc curred in response to more physiological stimuli, rats were injected subcutaneously with ACTH. Labeling of the 35,000 $M_{r}$ protein increased linearly in response to ACTH injections (4 hr) up to approximately 0.6 units/ 100 gm of body weight, with the maximal increase occurring when approximately 2 units of $\mathrm{ACTH}$ were injected per $100 \mathrm{gm}$ of body weight (Fig. 2A), corresponding to a serum corticosterone level of approximately $100 \mathrm{ng} / \mathrm{ml}$ (Fig. 2B). This dose of ACTH might be considered pharmacological, except that Meserve and I eatham (1981) have shown this type of ACTH injection (a subcutaneous injection in gelatin) produces a corticosterone response similar to that elicited by ether stress. Serum levels of corticosterone increased linearly with respect to the amount of injected ACTH up to at least 4 units injected per $100 \mathrm{gm}$ of body weight (Fig. $2 B$ ). The time course following an injection of 2 units/100 gm of body
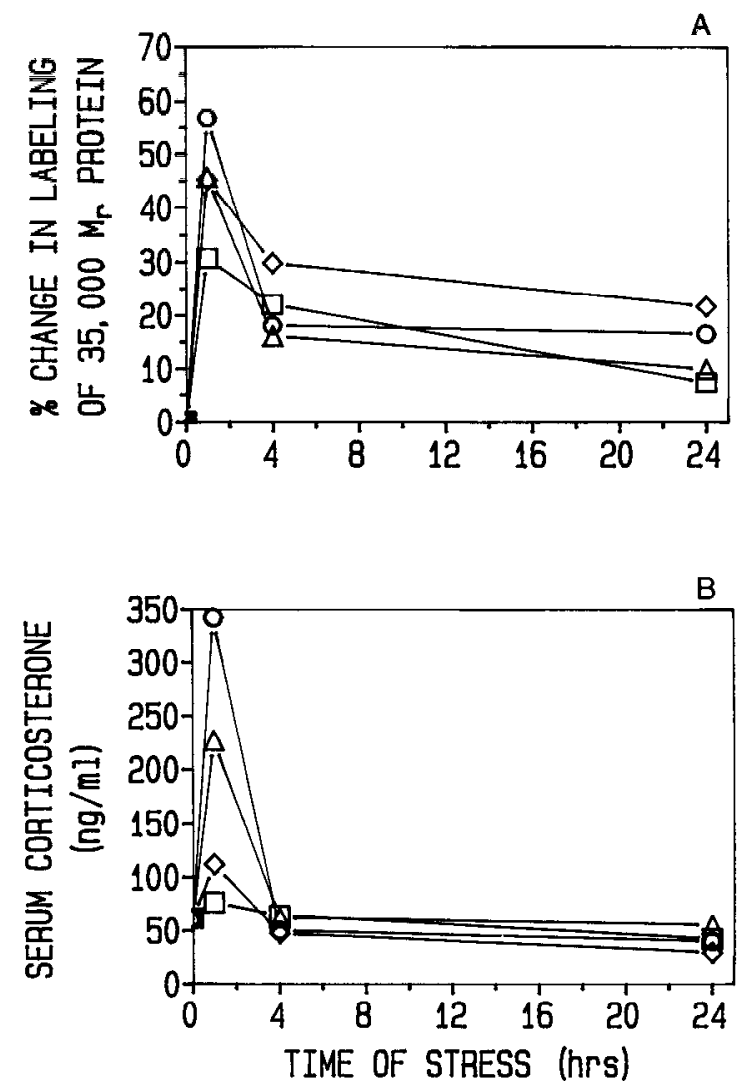

Figure 3. Time course of change in ${ }^{35} \mathrm{~S}$-methionine labeling of the $35,000 M_{r}$ hippocampal protein following various stresses to intact animals and corresponding serum corticosterone concentrations. $A$, percentage change in labeling over time when the stresses were performed the number of hours indicated $(1,4$, or 24) prior to death. The specific stresses were sham-injection $(\square)$, cold $(\diamond)$, ether $(\triangle)$, and immobilization $(O) . B$, The corresponding serum corticosterone concentrations for the stress time courses. Frror bars were omitted on all points for clarity. See text for significance of effects.

weight of ACTH indicated a maximal level of response in protein labeling of approximately $125 \%$ at $4 \mathrm{hr}$ (Fig. $2 \mathrm{C}$ ), when 1 , 4 , and $24 \mathrm{~h}$ time points were compared. Figure $2 D$ indicates that the serum levels of endogenous corticosterone increased after an injection of 2 units $/ 100$ gm of body weight, reaching a maximal value of approximately $200 \mathrm{ng} / \mathrm{ml}$ by $1 \mathrm{hr}$ after injection. The time of maximal increase in the synthesis of the 35,000 $M_{r}$ protein in response to ACTH injections therefore followed the time of maximal serum levels of corticosterone. When animals were adrenalectomized and injected $4 \mathrm{hr}$ prior to death with 2 units of ACTH/100 gm of body weight no increase in synthesis of the $35,000 M_{r}$ protein was observed (data not shown).

Since glucocorticoids are released endogenously when an animal is stressed, a series of animals were given various stresses to see if the synthesis of the $35,000 M_{r}$ protein could be increased. The stresses were as described in Materials and Methods, and the resultant increases in synthesis were obtained by comparing the labeling of the $35,000 M_{r}$ hippocampal protein from the stressed animals to that seen in naive animals. The maximal increases in labeling of the $35,000 M_{r}$ protein following stress all occurred $1 \mathrm{hr}$ after the stress (Fig. $3 \mathrm{~A}$ ). The increases in synthesis at $1 \mathrm{hr}$ were as follows: sham-injected, $30.69 \pm$ $6.75 \%(n=8)$; cold, $45.23 \pm 9.58 \%(n=4)$; ether, $45.63 \pm$ $13.46 \%(n=4)$; and immobilization, $56.80 \pm 6.40 \%(n=4)$. 

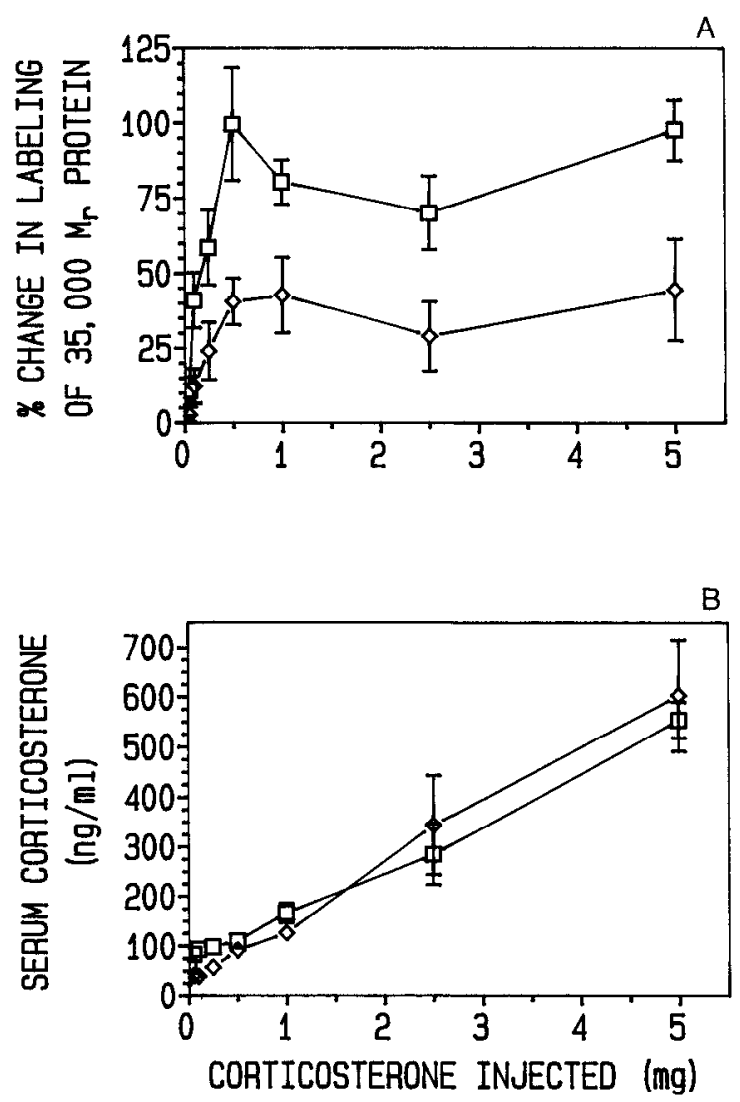

Figure 4. Corticosterone dose-response curves for increase in ${ }^{35} \mathrm{~S}-\mathrm{me}-$ thionine labeling of the $35,000 M$, hippocampal protein in intact and adrenalectomized animals. $A$, The dose-response curves for intact ( $\square$ ) and adrenalectomized $(\diamond)$ animals. Amounts of corticosterone injected per animal were from 0.05 to $5.0 \mathrm{mg}$. $B$, The corresponding serum corticosterone concentrations for both dose-response curves.

Increases in response to all stresses are significantly different from zero. When comparing protein labeling among the stresses, only the difference between immobilization and sham-injection was statistically significant. A series of rats that had been adrenalectomized and stressed 1 hr prior to death did not show a corresponding increase in synthesis of the $35,000 M_{r}$ protein (data not shown). The peak concentrations of corticosterone in the serum also occurred at $1 \mathrm{hr}$ and were as follows: shaminjected, $76.99 \pm 11.59 \mathrm{ng} / \mathrm{ml}$; cold, $111.92 \pm 18.77 \mathrm{ng} / \mathrm{ml}$; ether, $226.86 \pm 38.52 \mathrm{ng} / \mathrm{ml}$; and immobilization, $342.33 \pm$ $101.66 \mathrm{ng} / \mathrm{ml}$.

In order to ascertain if the increased labeling of the 35,000 $M_{r}$ protein correlated with binding of steroid to either the putative type I or type II receptor, a dose-response curve was performed on adrenalectomized rats with either corticosterone, aldosterone, or the synthetic corticosterone analog RU 28362. The dose-response curve for corticosterone in adrenalectomized rats (Fig. $4 A$ ) showed the maximal increase in synthesis of the $35,000 M_{r}$ protein occurred when approximately $0.5 \mathrm{mg}$ corticosterone was injected per animal. As was the case with the previous experiments, this corresponded to a serum corticosterone level of approximately $100 \mathrm{ng} / \mathrm{ml}$ (Fig. $4 B$ ). The increase in synthesis of the $35,000 M_{r}$ protein did not increase further above $0.5 \mathrm{mg}$ injected per animal (Fig. $4 A$ ), even though the serum corticosterone levels continued to rise linearly up to 5.0 mg injected per rat (Fig. 4B). This again was similar to that seen
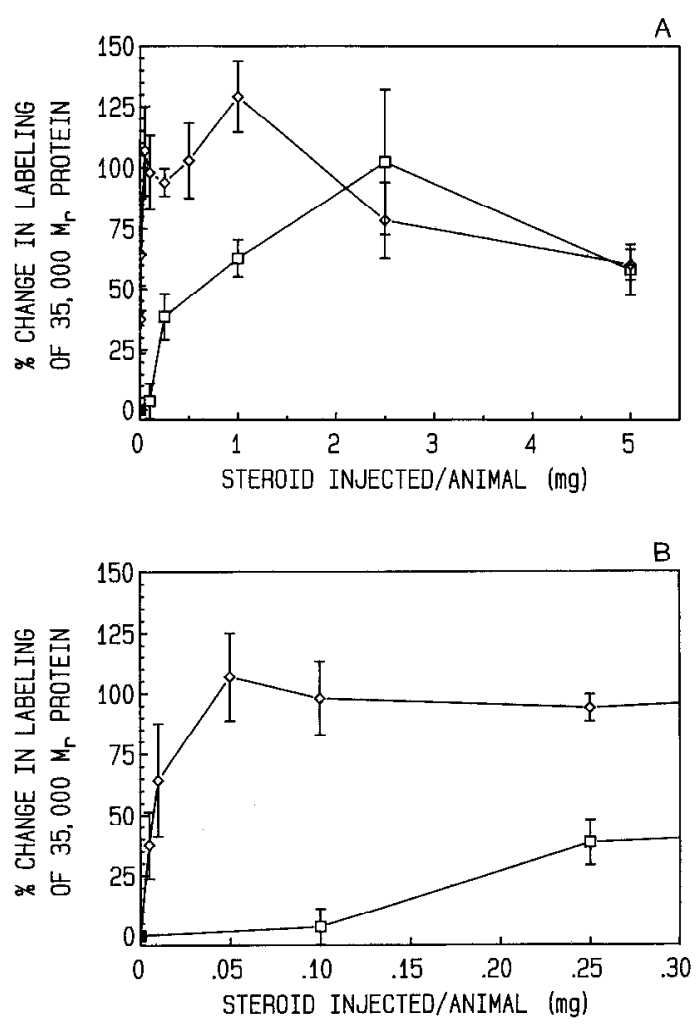

Figure 5. Dose-response curves for increase in ${ }^{35} \mathrm{~S}$-methionine labeling of the $35,000 M$, hippocampal protein in response to RU 28362 and aldosterone. $A$, The complete dose-response curve for aldosterone ( $\square$ ) and RU $28362(\diamond)$. For aldosterone, the amounts injected per rat were from 0.10 to $5.0 \mathrm{mg}$. For RU 28362, the amounts injected per animal were from 0.005 to $5.0 \mathrm{mg}$. $B$, For more clarity, the curves from 0 to $0.3 \mathrm{mg}$ injected per animal are shown.

in response to serum corticosterone levels produced with ACTH injections.

When dose-response curves for aldosterone and RU 28362 were compared, there was a significant difference between the 2 curves. Aldosterone caused a maximal increase $(102.4 \pm 29.9 \%$, $n=4)$ in synthesis of the $35,000 M_{r}$ protein when approximately $2.5 \mathrm{mg}$ was injected per animal (Fig. $5 \mathrm{~A}$ ). The maximal increase in protein labeling seen following injections of RU 28362 (106.9 $\pm 18.2 \%, n=6$ ), however, was observed when $0.05 \mathrm{mg}$ of the synthetic analog was injected, a 50 -fold difference in sensitivity compared with aldosterone (Fig. $5 B$ ).

Figure $4 A$ indicates a difference in hippocampal protein labeling in response to corticosterone in intact rats compared with adrenalectomized animals. The increase in synthesis of the 35,000 $M_{r}$ protein in intact animals was approximately twice that seen in adrenalectomized animals throughout the dosage range, yet the serum corticosterone levels were approximately the same for both groups of animals (Fig. 4B). The maximal increase in labeling of the $35,000 M_{r}$ protein obtained for both intact and adrenalectomized animals occurred when $0.5 \mathrm{mg}$ corticosterone was injected. For intact animals the increase was $99.8 \pm 18.9 \%$ $(n=4)$, while in adrenalectomized animals it was only $40.6 \pm$ $7.8 \%(n=4)$. The maximal increase in synthesis of the 35,000 $M_{r}$ protein occurred in both intact and adrenalectomized rats when serum corticosterone values were approximately $100 \mathrm{ng} /$ $\mathrm{ml}$ (Fig. 4B). 


\section{Discussion}

Hippocampal slices prepared from rats that had been subcutaneously injected with $5 \mathrm{mg}$ corticosterone and incubated with ${ }^{35} \mathrm{~S}-\mathrm{methionine}$ show an increase in synthesis of a $35,000 \mathrm{M}$, protein compared with slices from sham-injected rats. This increase appears to be tissue (Schlatter and Dokas, 1987) and steroid specific. Injections of $5 \mathrm{mg}$ corticosterone, dexamethasone, or aldosterone all produce comparable increases in the synthesis of this protein. Estradiol produces no significant effect, while the progesterone effect is relatively small. This last response may be pharmacological or may be a secondary effect of progesterone. It has been shown (McEwen et al., 1976), that although progesterone will bind to a corticosterone receptor, the progesterone-receptor complex produces no known functional response.

The maximal increase in synthesis of the hippocampal protein is the same independent of corticosterone source. Whether produced endogenously through stress or ACTH injections or through exogenous injections of the steroid, whenever serum corticosterone values reach approximately $100 \mathrm{ng} / \mathrm{ml}$ the increase in synthesis of the $35,000 M_{r}$ protein is maximal. The most probable limiting factor is the finite number of available hippocampal receptors for the steroid. Rotsztejn et al. (1975) indicated that the amount of bound corticosterone in the hippocampus reached a maximum when a total dose of $0.23 \mathrm{mg}$ of corticosterone was infused into approximately $200 \mathrm{gm}$ animals (the weight of animals used in the present study). The maximal increase observed in protein labeling in this study occurred after $0.5 \mathrm{mg}$ corticosterone was injected per rat. Rotsztcjn ct al. also obscrved continucd lincar increascs in scrum corticosterone concentration at infusion doses that produced no further increase in hippocampal binding of corticosterone. McEwen et al. (1974) also showed a maximal binding capacity of corticosterone in the hippocampus when the steroid was injected exogenously.

The 2 putative glucocorticoid receptors have varying affinity for the steroids used in these experiments. Binding of the synthetic glucocorticoid RU 28362 occurs exclusively to the type II receptor (Hermann et al., 1987), which has an affinity for corticosterone approximately 10 times lower than the type I receptor (Reul and de Kloet, 1985). Aldosterone has a reported $K_{d}$ for the type II receptor of approximately $29.8 \mathrm{nM}$ (Veldhuis et al., 1982; de Kloet and Reul, 1987), while RU 28362 has a reported $K_{d}$ of 1.2-2 nM for the same receptor (Reul and de Kloet, 1985). Reul and de Kloet (1985) have also shown that the type I receptors are approximately $90 \%$ occupied at basal serum corticosterone levels, while only $10 \%$ of the type II receptors are occupied at this time. Type II receptors are the only receptors available at elevated serum levels of corticosterone. Since the hippocampal protein labeling effect in response to corticosterone is not maximal until plasma levels of the steroid are elevated to the stress range $(100 \mathrm{ng} / \mathrm{ml})$, regardless of their source, our data are most consistent with an involvement of the type II receptor.

A similar conclusion can be reached by comparing the relative abilities of corticosterone, aldosterone and RU 28362 to increase the labeling of the hippocampal $35,000 M_{r}$ protein after injection into adrenalectomized rats. The relative $K_{d}$ values of the type II receptor for RU 28362 and aldosterone suggest that the former steroid should be much more effective than aldosterone in activation of type II receptor-mediated responses. We have found maximal labeling of the hippocampal $35,000 M_{r}$ protein to be approximately 50 -fold more sensitive to RU 28362 than to aldosterone. Likewise, the sensitivity of protein labeling to RU 28362 as compared with corticosterone (approximately 10 -fold) is consistent with a higher affinity of the type II receptor for the synthetic analog than for corticosterone. RU 28362 has negligible affinity for the type I receptor, while corticosterone has a higher affinity for the type I receptor than for the type II receptor. If a type I response were being observed in these studies, a reverse potency of RU 28362 and corticosterone would have been expected. Furthermore, aldosterone has been shown to block activation of tryptophan hydroxylase by low doses of corticosterone following adrenalectomy (de Kloet et al., 1983), implying that at type I receptors, aldosterone may be a functional antagonist. Our results are more consistent with an agonistic action of aldosterone at the type II receptor when it is present at high concentrations in vivo. However, because of the very high doses of aldosterone needed in vivo to increase the labeling of the $35,000 M_{r}$ protein and the relatively low concentration of extravascular transcortin in the hippocampus (de Kloet and Reul, 1987) which favors the availability of corticosterone as compared with aldosterone for the type II receptor in intact rats, it seems unlikely that this effect of aldosterone is physiologically relevant. The same degree of increase in labeling of the $35,000 M_{r}$ hippocampal protein was seen in response to $5 \mathrm{mg}$ aldosterone regardless of whether intact or adrenalectomized rats were used (compare Figs. $1 B$ and $5 A$ ), eliminating a secondary release of corticosterone in response to the stress of the aldosterone injections as an explanation for the effect.

Given the evidence that the type II receptor is involved in increased labcling of the $35,000 M$, protein, this protein may correlate with hippocampal functions known to be mediated by this receptor, most notably, negative feedback regulation of the hypothalamic-pituitary-adrenal axis (Reul and de Kloet, 1985). Stimuli that raise endogenous levels of corticosterone and secondarily produce such negative-feedback inhibition (ACTH and several stressors) also increase the labeling of the hippocampal protein. The time period of elevated protein labeling following endogenous stress is of very rapid onset and of short duration, implying that it may serve an adaptive, flexible function in the hippocampus with regard to regulation of stress responses.

The difference in the dose-response curves for corticosterone in the synthesis of the $35,000 M_{r}$ protein between intact and adrenalectomized rats is significant. While both curves show the same sensitivity and general shape, the intact animals have a maximal increase approximately $100 \%$ higher than that seen in adrenalectomized rats. This cannot be due to endogenous corticosterone secretion caused by the stress of handling in intact animals since the appropriate controls (sham-injection with vehicle alone) were used for comparison for both curves. At the higher dosages, any released endogenous corticosterone would be negligible anyway, given the $100 \mathrm{ng} / \mathrm{ml}$ of serum corticosterone limit on the maximal response in protein labeling.

There are a number of possible reasons for the differences in the response. One is that increased labeling of the hippocampal protein is sensitive to factors other than glucocorticoids that are also removed by adrenalectomy. Interactions between glucocorticoids and catecholamines have previously been noted. Breen et al. (1978) found in cultured cerebral cells that norepinephrine acts at the transcriptional level to potentiate the glucocorticoidinduced synthesis of glycerol 3-phosphate dehydrogenase (E.C. 1.1.1.8). Others have shown that both glucocorticoids (Bo- 
hus et al., 1982) and catecholamines (Borrell et al., 1983) are involved in the hippocampus with regard to learning and memory. Since adrenalectomy removes not only endogenous corticosterone but also the adrenal medulla-produced catecholamines, a synergistic effect of the 2 compounds could explain the higher synthesis of the hippocampal protein in intact animals. This would be complex, however, since catecholamines have not been shown to cross the blood-brain barrier. Second, adrenalectomy would remove the endogenous source of aldosterone that might be needed in addition to corticosterone. However, as previously mentioned, aldosterone blocks type I receptor-like actions of corticosterone (de Kloet et al., 1983), and our data suggest a minimal physiological role for aldosterone at type II receptors.

The increased hippocampal corticosterone receptor capacity of adrenalectomized animals (McEwen et al., 1974) cannot be the cause since this would favor a larger response in adrenalectomized, as compared with intact, rats following administration of exogenous steroid. We observe the opposite. If adrenalectomy had any effect on transcortin concentration or affinity, this might determine the level of competition between aldosterone and corticosterone for the same receptors, but with aldosterone being eliminated by adrenalectomy and the high dosages minimizing the effect of transcortin, this is not a likely source of the difference in protein synthesis. Finally, it is possible that adrenalectomy-induced alterations in hippocampal function may indirectly influence protein metabolism. Cholinergic (Gilad et al., 1985), serotonergic (de Kloet et al., 1983), GABAergic (Majewska et al., 1985), noradrenergic (Harrelson et al., 1983), and neuropeptide (Rotsztejn et al., 1980) systems of the hippocampus are all sensitive to manipulation of glucocorticoid levels. Alterations in any of these systems might diminish the responsiveness of the hippocampus to exogenous steroid in adrenalectomized rats.

The identity of this hippocampal protein is currently unknown. It is similar in molecular weight and steroid responsiveness to a translation product from hippocampal mRNA described by Nichols et al. (1988). The glucocorticoid-inducible glial enzyme glycerol 3-phosphate dehydrogenase (GPDH) is a dimer with 2 identical subunits of approximately $35,000 M_{r}$ (de Vellis and Inglish, 1968; McGinnis and de Vellis, 1974). The possibility that the hippocampal protein is GPDH is currently being investigated. Maintenance of GPDH activity by glucocorticoids would be functionally adaptive since it would restore energy reserves. Furthermore, glucocorticoids have been shown to induce heat-shock proteins in lymphocytes, one of whose $M_{r}$ and isoelectric point match those of the hippocampal protein (Colbert and Young, 1987; L. K. Schlatter, S. M. Ting, and L. A. Dokas, unpublished observations). Given the interrelatedness of steroids and the heat-shock proteins (Baez et al., 1987; Sanchez et al., 1987), a common identity of these proteins must also be considered.

\section{References}

Baez, M., P. R. Sargan, A. Elbrecht, M. S. Kulomaa, T. Zarucki-Schulz, M.-J. Tsai, and B. W. O'Malley (1987) Steroid hormone regulation of the gene encoding the chicken heat-stock protein Hsp 108. J. Biol. Chem. 262: 6582-6588.

Barseghian, G., and R. Levine (1980) Effect of corticosterone on insulin and glucagon secretion by isolated perfused rat pancreas. Endocrinology 106: 547-552.

Bohus, B., E. R. de Kloet, and H. D. Veldhuis (1982) Adrenal steroids and behavioral adaptation: Relationship to brain corticoid receptors.
In Current Topics in Neuroendocrinology: Adrenal Actions on Brain, D. Ganten and D. Pfaff, eds., pp. 107-148, Springer-Verlag, Berlin.

Borrell, J., E. R. de Kloet, D. H. G. Versteeg, and B. Bohus (1983) Inhibitory avoidance deficit following short-term adrenalectomy in the rat: The role of adrenal catecholamines. Beh. Neural Biol. 39: 241-258.

Breen, G. A. M., J. F. McGinnis, and J. de Vellis (1978) Modulation of the hydrocortisone induction of glycerol phosphate dehydrogenase by $\mathrm{N}^{6}, \mathrm{O}^{2}$-dibutyryl cyclic AMP, norepinephrine, and isobutylmethyllaxanthine in rat brain cell cultures. J. Biol. Chem. 253: 2554-2562.

Butte, J. C., R. Kakihani, and E. P. Noble (1976) Circadian rhythm of corticosterone levels in rat brain. J. Endocrinol. 68: 235-239.

Colbert, R. A., and D. A. Young (1987) Detection of mRNAs coding for translationally regulated heat-shock proteins in non-heat-shocked thymic lymphocytes. J. Biol. Chem. 262: 9939-9941.

de Kloet, E. R., and J. M. H. M. Reul (1987) Feedback action and tonic influences of corticosteroids on brain function: A concept arising from the heterogeneity of brain receptor systems. Psychoneuroendocrinology 12: 83-105.

de Kloet, E. R., D. H. G. Versteeg, and G. L. Kovacs (1983) Aldosterone blocks the response to corticosterone in the raphe-hippocampal serotonin system. Brain Res. 264: 323-327.

de Vellis, J., and D. Inglish (1968) Hormonal control of glycerolphosphate dehydrogenase in the rat brain. J. Neurochem. 15: 10611070.

Etgen, A. M., K. S. Lee, and G. Lynch (1979) Glucocorticoid modulation of specific protein metabolism in hippocampal slices maintained in vitro. Brain Res. 165: 37-45.

Feldman, S., and N. Conforti (1980) Participation of the dorsal hippocampus in the glucocorticoid feedback effect on adrenocortical activity. Neuroendocrinology 30: 52-55.

Fuxe, K., A. Wikstrom, S. Okret, L. F. Agnati, A. Harfstrand, Z. Yu, L. Granholm, M. Zoli, W. Vale, and J.-A. Gustafsson (1985) Mapping of glucocorticoid receptor immunoreactive neurons in the rat tel- and diencephalon using a monoclonal antibody against rat liver glucocorticoid receptor. Endocrinology 117: 1803-1812.

Gilad, G. M., B. D. Mahon, Y. Finkelstein, B. Koffler, and V. H. Gilad (1985) Stress-induced activation of the hippocampal cholinergic system and the pituitary-adrenocortical axis. Brain Res. 347: 404-408.

Granner, D. K., and E. G. Beale (1985) Regulation of the synthesis of tyrosine aminotransferase and phosphoenolpyruvate carboxykinase by glucocorticoid hormones. In Biochemical Actions of Hormones, Vol. 12, G. Litwack, ed., pp. 89-138, Academic, New York.

Harrelson, A. L., B. S. McEwen, and W. Rostene (1983) Adrenalectomy modifies neurotransmitter-stimulated cyclic AMP accumulation in hippocampal slices. Soc. Neurosci. Abstr. 9: 87.

Hermann, T., K. Schramm, and R. Ghraf (1987) Photoaffinity labeling with $\left[{ }^{3} \mathrm{H}\right]-\mathrm{RU}$ 28362: A powerful tool for the study of rat brain glucocorticoid receptors. J. Steroid Biochem. 26: 417-423.

Karlsen, K., A. K. Vallerga, J. Howe, and G. L. Firestone (1986) A distinct glucocorticoid hormone response regulates phosphoprotein maturation in rat hepatoma cells. Mol. Cell. Biol. 6: 575-585.

Lowry, O. H., N. J. Rosenbrough, A. L. Farr, and R. J. Randall (1951) Protein measurement with the Folin phenol reagent. J. Biol. Chem. 193: 265-275.

Lust, W. D., T. S. Whittingham, and J. V. Passonneau (1982) Effects of slice thickness and method of preparation on energy metabolism in the in vitro hippocampus. Soc. Neurosci. Abstr. 8: 1000.

Majewska, M. D., J.-C. Bisserbe, and R. L. Eskay (1985) Glucocorticoids are modulators of $\mathrm{GABA}_{\mathrm{A}}$ receptors in brain. Brain Res. 339: $178-182$

McEwen, B. S., G. Wallach, and C. Magnus (1974) Corticosterone binding to hippocampus: Immediate and delayed influences of the absence of adrenal secretion. Brain Res. 70: 321-334.

McEwen, B. S., E. R. de Kloet, and G. Wallach (1976) Interactions in vivo and in vitro of corticoids and progesterone with cell nuclei and soluble macromolecules from rat brain regions and pituitary. Brain Res. 105: 129-136.

McGinnis, J. F., and J. de Vellis (1974) Purification and characterization of rat brain glycerol phosphate dehydrogenase. Biochim. Biophys. Acta 364: 17-27.

Meserve, L. A., and J. H. Leatham (1981) Development of hypothalamic-pituitary-adrenal response to stress in rats made hypothyroid by exposure to thiouracil from conception. J. Endocrinol. 90: 403409.

Munck, A., P. M. Guyre, and N. J. Holbrook (1984) Physiological 
functions of glucocorticoids in stress and their relation to pharmacological actions. Endocrine Rev. 5: 25-44.

Nestler, E. J., T. C. Rainbow, B. S. McEwen, and P. Greengard (1981) Corticosterone increases the amount of protein I, a neuron-specific phosphoprotein, in rat hippocampus. Science 212: 1162-1164.

Nichols, N. R., S. P. Lerner, J. N. Masters, P. C. May, S. L. Millar, and C. E. Finch (1988) Rapid corticosterone-induced changes in gene expression in rat hippocampus display type II glucocorticoid receptor specificity. Mol. Endocrinol. 2: 284-290.

Reihold, C. T., T. J. Teyler, and R. M. Vardaris (1984) Effects of corticosterone on the electrophysiology of hippocampal CA1 pyramidal cells in vitro. Brain Res. Bull. 12: 349-353.

Reul, J. M. H. M., and E. R. de Kloet (1985) Two receptor systems for corticosterone in rat brain: Microdistribution and differential occupation. Endocrinology 117: 2505-2511.

Rotsztejn, W. H., M. Normand, J. LaLonde, and C. Fortier (1975) Relationship between ACTH release and corticosterone binding by the receptor sites of the adenohypophysis and dorsal hippocampus following infusion of corticosterone at a constant rate in the adrenalectomized rat. Endocrinology 97: 223-230.

Rotsztejn, W. H., J. Besson, B. Briaud, L. Gagnant, G. Rosselin, and
C. Kordon (1980) Effects of steroids on vasoactive intestinal peptide in discrete brain regions and peripheral tissues. Neuroendocrinology 31: 287-291.

Sanchez, E. R., S. Meshinchi, M. J. Schlesinger, and W. B. Pratt (1987) Demonstration that the 90 -kilodalton heat shock protein is bound to the glucocorticoid receptor in its $9 \mathrm{~S}$ nondeoxynucleic acid binding form. Mol. Endocrinol. 1: 908-912.

Sapolsky, R. M., L. C. Krey, and B. S. McEwen (1986) The neuroendocrinology of stress and aging: The glucocorticoid cascade hypothesis. Endocrine Rev. 3: 284-301.

Schlatter, L. K., and L. A. Dokas (1987) Glucocorticoid-stimulated $\left[{ }^{35} \mathrm{~S}\right]$-labcling of a cytosolic protein in the rat hippocampus. Neurosci. Res. Commun. 1: 71-78.

Vannice, J. L., J. M. Taylor, and G. M. Ringold (1984) Glucocorticoidmediated induction of $\alpha_{1}$-acid glycoprotein: Evidence for hormoneregulated RNA processing. Proc. Natl. Acad. Sci. USA 81: 42414245.

Veldhuis, H. D., C. Van Koppen, J. Van Ittersum, and E. R. de Kloet (1982) Specificity of the adrenal steroid receptor system in rat hippocampus. Endocrinology 110: 2044-2051. 